\title{
Accumulation of lead and zinc in chosen medicinal plants from Katowice recreation area
}

\author{
Kumulacja ołowiu i cynku w wybranych roślinach leczniczych \\ z terenów rekreacyjnych Katowic
}

\begin{abstract}
*Mgr Anna Laskowska, dr hab. Danuta Wiechuła, Department of Toxicology,
School of Pharmacy with the Division of Laboratory Medicine, Medical

University of Silesia in Katowice, Jagiellońska 4St., 41-200 Sosnowiec,

e-mail: toksykologia@sum.edu.pl
\end{abstract}

Keywords: medicinal plants, phytoaccumulation, $\mathrm{Pb}, \mathrm{Zn}$, heavy metals, herbal medicine

Słowa kluczowe: rośliny lecznicze, fitokumulacja, $\mathrm{Pb}, \mathrm{Zn}$, metale ciężkie, ziołolecznictwo

\begin{abstract}
The aim of this research was to assess the concentration of lead and zinc in chosen medicinal plants obtained from recreational areas of Katowice as well as to compare the phytoaccumulation properties of these plants. Lead and zinc concentration in plants and soil was indicated with flame and flameless atomisation atomic absorption spectroscopy AAS method. Phytoaccumulation properties of examined plant species were compared using the coefficients: enrichment factor, phytoaccumulation factor and coefficient of specific relative accumulation.
\end{abstract}

(c) IOŚ-PIB

\section{INTRODUCTION}

Heavy metals found as natural components of the Earth's crust, usually occur in all environmental matrices. However, the concentration of some of them increases significantly in some ecosystems, as a result of anthropogenic human activity [Sarma et al. 2011, Nadgórska-Socha et al. 2013]. Among the potential sources of environmental pollution with heavy metals, there are distinguished among others the industry, energetics and communication [Gruca-Królikowska, Wacławek 2006; KabataPendias, Pendias 1999].

Heavy metals occurrence in the environment causes them to also accumulate in medicinal plants, used in the herbal medicine [Sarma et al. 2011, Nadgórska-Socha et al. 2013], which in recent years has aroused great interest [Kabata-Pendias, Pendias 1999, Blicharska et al. 2007]. Apart from biologically active compounds, products produced from medicinal plants, as well as very raw materials, can be polluted among others with heavy metals, remains of artificial fertilisers or pesticides [Kabata-Pendias, Pendias 1999, Blicharska et al. 2007; Srogi 2005]. The content of these pollutants depends on raw material type and origin as well as quality and quantitative composition of herbal preparations [Blicharska et al. 2007].

The aim of this study was an evaluation of lead and zinc accumulations in chosen medicinal plants obtained from recreational areas of Katowice, which may potentially constitute a place of collection of medicinal plants for own purposes and comparison, to what extent and with what force the selected plant species accumulate zinc and lead.

\section{Streszczenie}

Celem badań była ocena zawartości ołowiu i cynku w wybranych roślinach leczniczych pozyskanych z terenów rekreacyjnych Katowic oraz porównanie właściwości fitokumulacyjnych tych roślin. Zawartość ołowiu oraz cynku w roślinach i glebie oznaczono metodą płomieniową i bezpłomieniową AAS. Właściwości fitokumulacyjne badanych gatunków roślin porównano przy pomocy współczynników: wzbogacenia, fitokumulacji oraz specyficznej kumulacji.

\section{MATERIAL AND METHODS}

For accomplishment of this work objective, a concentration of lead and zinc in 10 species of medicinal plants collected from the Valley of Three Ponds area in Katowice was indicated, as well as in surface layer of soil. For examinations, the following species of medicinal plants were chosen: ribwort plantain (Plantago lanceolata L.), blackberry bush (Rubus plicatus W. et N.), yarrow (Achillea millefolium L.), small-leaved lime (Tilia cordata Mill.), red raspberry (Rubus idaeus L.), common nettle (Urtica dioica L.), wild strawberry (Fragaria vesca L.), pineapple weed (Chamomilla suaveolens (Pursh) Rydb.), field horsetail (Equisetum arvense L.) and shepherd's-purse (Capsella bursa - pastoris L.).

Collected plants were dried in airy and dry conditions. Next, they were ground in a mortar and mineralised on drily. Obtained ash, after cooling down, was set with $65 \% \mathrm{HNO}_{3}$, quantitatively were transferred to measuring small flasks and supplemented with deionised water up to $25 \mathrm{~cm}^{3}$ volume [Ostrowska et al. 1991]. Air dry soil was ground in a mortar and consolidated a size of grains. Samples of approximately $1 \mathrm{~g}$ weight were transferred to conical small flasks and were set with $65 \% \mathrm{HNO}_{3}$. After 24 hours on a heating plate at a temperature of $130^{\circ} \mathrm{C}$, the acid evaporated and dry remains using $65 \% \mathrm{HNO}_{3}$ were transferred to small flasks and supplemented with deionised water up to 50 $\mathrm{cm}^{3}$ volume, next filtered.

$\mathrm{Pb}$ and $\mathrm{Zn}$ concentration in samples of plants and soil were indicated with flame and flameless atomisation method of atomic absorption 
spectrometry using a spectrometer AAS3. Correctness of applied methodology was assessed by standard addition method.

In statistical study, the following programmes were applied: STATISTICA 10 and Microsoft Office Excel 2007. The above study of distribution of metals concentration in plant samples showed that it diverged from a normal distribution; therefore, for evaluating the relevant differences between groups, the analysis of variance (ANOVA) test of Kruskala-Wallisa rank was used. Cumulative capacity of examined herbalist's raw materials with reference to $\mathrm{Pb}$ and $\mathrm{Zn}$ were assessed based on the following coefficients: phytoaccumulation factor (WF), enrichment factor (EF) and coefficient of specific relative accumulation (CSRA).

WF illustrates an average ability of plants to accumulate metals from the soil, and it is calculated as a ratio of metal concentration in the plant to metal content of the soil. WF values greater than 1 indicate an intensive accumulation of metals in the plant, values from 0.1 up to 1 - average, from 0.01 up to 0.1 - weak, and lower than 0.01 - lack of accumulation [Łaszewska et al. 2007, Stawinoga et al. 2007].

EF shows migration of metals to the plant from soil layers in relation to a reference element. It is calculated as a quotient ratio of examined metal amount in the plant and in the soil up to concentration quotient of this metal in referential plant and soil attempt [Loska et al. 2005].

CSRA characterises specificity of elements collection by plants belonging to a particular species. It is calculated by dividing the concentration of element in the plant by an average this element concentration in all other plants appearing in the same area [Stawinoga et al. 2007].

\section{RESULTS AND DISCUSSION}

Table 1 presents concentration of lead and zinc in individual species of medicinal plants.

From all examined plants, the median of lead concentration amounted to $11.94 \mu \mathrm{g} / \mathrm{g}$ s.m. In plants from so-called 'clean' areas, its average concentration does not exceed $3 \mu \mathrm{g} / \mathrm{g}$ [Kabata-Pendias, Pendias 1999]. The concentration of lead in samples of individual plants was characterised by a very large diversity, from the smallest (median $4.40 \mu \mathrm{g} / \mathrm{g}$ ) in small-leaved lime, to the largest (median $29.10 \mu \mathrm{g} / \mathrm{g}$ ) stated in wild strawberry; however, all results exceeded the level of $3 \mu \mathrm{g} / \mathrm{g}$. Even greater spread of lead concentration was stated in Wang et al. analysis [Wang et al. 2012].

The WHO acceptable concentration of lead in plants applied therapeutically was established at the level of $10 \mu \mathrm{g} / \mathrm{g}$ [WHO 1989]. Comparing obtained results with this norm, it is possible to state that out of examined herbs, only samples of the yarrow, small-leaved lime and pineapple weed met presented requirement and could be used in the production of herbal medicine.

The median of zinc concentration in analysed plant species amounted to $122.34 \mu \mathrm{g} / \mathrm{g}$ and ranged from the smallest value $(33.97 \mu \mathrm{g} / \mathrm{g})$ in yarrow to the largest in wild strawberry (1127.41 $\mu \mathrm{g} / \mathrm{g})$.

Analysing obtained medians of metals in the soil concentration, amounting appropriately to $96.05 \mu \mathrm{gPb} / \mathrm{g}$ and $175.87 \mu \mathrm{gZn} / \mathrm{g}$, we can observe a large variation in the values associated with proximity, as well as a variety of pollutants emission sources. The soil from Silesian town area Kicińska [Kicińska 2011] indicated an average amount of both metals at a much higher level: $\mathrm{Pb}-1940.25 \mu \mathrm{g} / \mathrm{g}$ and $\mathrm{Zn}$ - in a scope of $414-1451 \mu \mathrm{g} / \mathrm{g}$. Findings of Dmochowski et al. [Dmochowski et al. 2011] indicate a decline of metals in the soil along with increasing distances from the route. The concentration of metals in the soil also influenced the concentration of organic substance and $\mathrm{pH}$ of the soil.

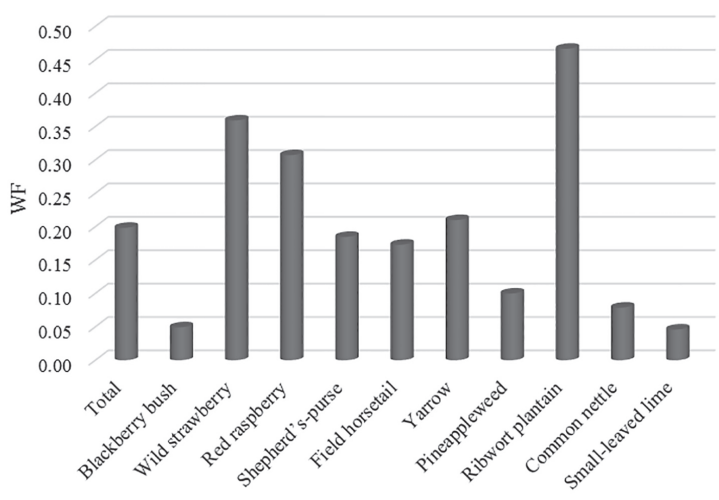

Fig. 1. Value of phytoaccumulation factor lead

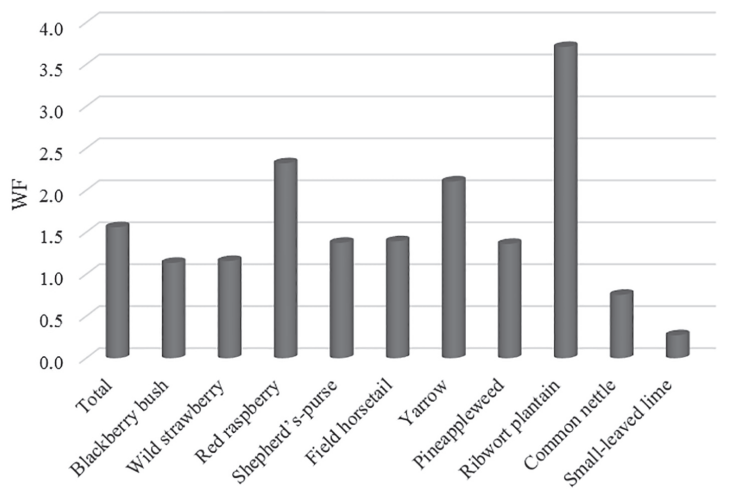

Fig. 2. Value of phytoaccumulation factor zinc

Degree of $\mathrm{Pb}$ and $\mathrm{Zn}$ accumulation through examined species of medicinal plants were assessed based on the value of WF Fig. 1 and Fig. 2. Value of lead WF in examined plant species indicates an average degree of this metal accumulation. Only yarrow, small-leaved lime, common nettle and pineapple weed were characterised by a weak tendency to accumulate lead. Considerable values of the WF were calculated for ribwort plantain (0.45). Obtained values were similar to those calculated for the plants of Lower Silesia region [Wiechuła et al. 2013]; however, higher values of WF were obtained by Łaszewska et al. [Łaszewska et al. 2007].

Values of zinc WF were greater than those received for lead and pointed at an intense degree of zinc accumulation in examined plants. Similar results were observed in studies of Szwalec et al. [Szwalec et al. 2013], Wiechuła et al. [Wiechuła et al. 2013], as well as Łaszewska et al. [Łaszewska et al. 2007].

Based on the value of EF, it was found that wild strawberry was characterised by a strong enrichment of lead and average 
Table 1. $\mathrm{Pb}$ and $\mathrm{Zn}$ concentration in individual plant species from the Valley of Three Ponds area $[\mu \mathrm{g} / \mathrm{g}]$

\begin{tabular}{|c|c|c|c|c|c|c|c|c|c|c|}
\hline \multirow[b]{2}{*}{ Species } & \multicolumn{5}{|c|}{$\mathrm{Pb}$} & \multicolumn{5}{|c|}{$\mathrm{Zn}$} \\
\hline & $\begin{array}{c}\text { Arithmetic } \\
\text { mean }\end{array}$ & Median & Minimum & Maximum & $\begin{array}{l}\text { Standard } \\
\text { deviation }\end{array}$ & $\begin{array}{c}\text { Arithmetic } \\
\text { mean }\end{array}$ & Median & Minimum & Maximum & $\begin{array}{l}\text { Standard } \\
\text { deviation }\end{array}$ \\
\hline $\begin{array}{l}\text { Blackberry } \\
\text { bush (Rubus } \\
\text { plicatus W. } \\
\text { et N.) }\end{array}$ & 12.20 & 11.68 & 8.32 & 17.59 & 2.20 & 133.43 & 122.58 & 78.42 & 216.39 & 40.07 \\
\hline $\begin{array}{c}\text { Wild } \\
\text { strawberry } \\
\text { (Fragaria } \\
\text { vesca L.). }\end{array}$ & 47.32 & 29.10 & 17.07 & 105.56 & 33.64 & 437.89 & 189.30 & 102.95 & 1127.41 & 405.16 \\
\hline $\begin{array}{c}\text { Red raspberry } \\
\text { (Rubus } \\
\text { idaeus L.) }\end{array}$ & 12.33 & 11.46 & 6.88 & 18.29 & 3.60 & 102.28 & 104.02 & 75.25 & 139.79 & 20.66 \\
\hline $\begin{array}{c}\text { Shepherd's- } \\
\text { purse } \\
\text { (Capsella bursa } \\
\text { - pastoris L.) }\end{array}$ & 18.70 & 17.33 & 9.88 & 27.94 & 6.56 & 336.74 & 322.98 & 84.71 & 743.26 & 193.62 \\
\hline $\begin{array}{c}\text { Field horsetail } \\
\text { (Equisetum } \\
\text { arvense L.) }\end{array}$ & 12.82 & 12.60 & 9.47 & 19.53 & 2.40 & 236.78 & 257.47 & 46.81 & 420.44 & 146.99 \\
\hline $\begin{array}{c}\text { Yarrow } \\
\text { (Achillea } \\
\text { millefolium L.). }\end{array}$ & 6.62 & 6.30 & 2.41 & 9.98 & 2.57 & 146.49 & 57.24 & 33.97 & 442.69 & 139.23 \\
\hline $\begin{array}{c}\text { Pineapple } \\
\text { weed } \\
\text { (Chamomilla } \\
\text { suaveolens } \\
\text { (Pursh) Rydb.). }\end{array}$ & 8.48 & 7.28 & 4.58 & 14.65 & 3.05 & 145.83 & 155.85 & 108.77 & 174.18 & 20.25 \\
\hline $\begin{array}{c}\text { Ribwort } \\
\text { plantain } \\
\text { (Plantago } \\
\text { lanceolata L.). }\end{array}$ & 14.58 & 12.61 & 8.73 & 25.19 & 5.53 & 132.54 & 139.63 & 68.78 & 191.66 & 45.75 \\
\hline $\begin{array}{c}\text { Common } \\
\text { nettle (Urtica } \\
\text { dioica L.). }\end{array}$ & 19.02 & 16.08 & 8.76 & 34.83 & 7.62 & 127.57 & 100.67 & 69.55 & 254.14 & 61.48 \\
\hline $\begin{array}{l}\text { Small-leaved } \\
\text { lime (Tilia } \\
\text { cordata Mill.). }\end{array}$ & 5.44 & 4.40 & 1.71 & 12.31 & 3.62 & 59.61 & 63.26 & 35.73 & 77.03 & 14.29 \\
\hline
\end{tabular}

of zinc (Pb-6.44, Zn-4.73); however, the poorest enrichment was characteristic for small-leaved lime ( $\mathrm{Pb}-0.74, \mathrm{Zn}-0.64)$.

Investigation of specific cumulative properties of examined plant species were carried out based on the value of CSRA Fig. 3. Results confirm findings based on WF as well as enable to conclude that Fragaria vesca was characterised by the greatest cumulative capacity of both metals, whereas the smallest - smallleaved lime. For individual plants, the values of CSRA ranged between 0.44 and 3.87 for lead and 0.43 and 3.77 for zinc.

To compare the cumulative properties of individual plants based on WF, the cluster analysis method was used. Cluster analysis is a method of data classification, in which using a selected measure distance (in our case, it was a Euclidean distance) as well as defined principle of the agglomerative cluster (Ward's method), the experimental data are assigned to groups about similar properties. Result of cluster analysis is a hierarchical tree graph that is dendrogram - Figs. 4 and 5. Fig. 4 shows cluster

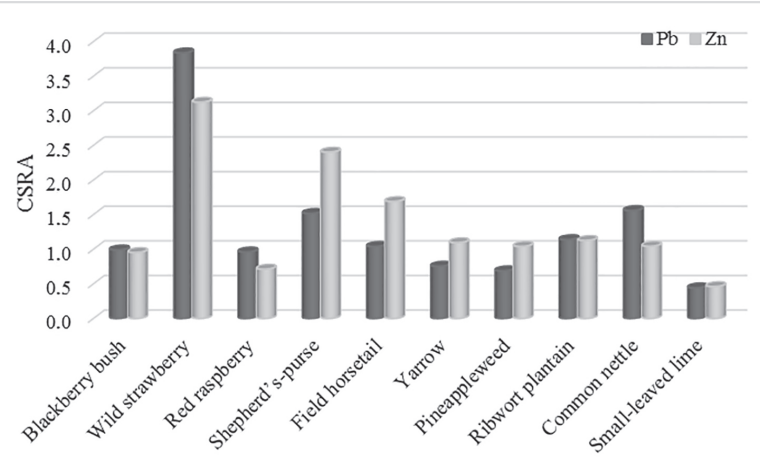

Fig. 3. Value of coefficient of specific relative accumulation (CSRA) for individual plant species

analysis results of the value of lead WF for individual plants. The most characteristic cluster is formed of plant species with the weakest cumulative properties - blackberry bush, small-leaved 


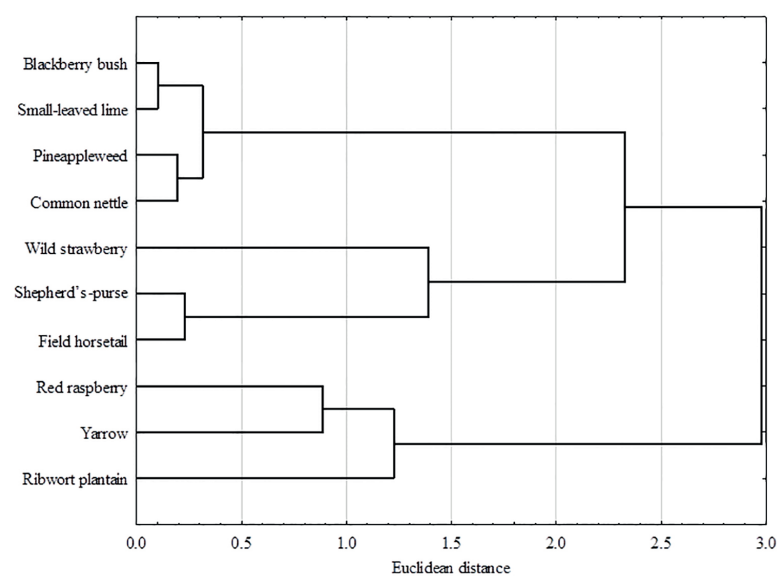

Fig. 4. Dendrogram, which illustrates resemblance of lead accumulation by individual species of medicinal plants

lime, common nettle and pineapple weed. Second cluster is formed of wild strawberry, shepherd's-purse and field horsetail. Separate cluster constitute plants with the largest degree of lead accumulation - red raspberry, yarrow and ribwort plantain, uniting in a distance combination of 2.4 with two remaining clusters. Slightly different clusters were received classifying values of zinc-specific WF in plants - Fig. 5. Characteristic plants cluster with the most poor zinc accumulation included blackberry bush, common nettle and small-leaved lime. Separate cluster formed red raspberry with ribwort plantain.

Analysis of the elements concentration in plants constitutes an important element in the evaluation of herbalist's raw material in terms of quality. In some plant raw materials, metals accumulation may lead to weakening of medicinal properties of plants and adversely affect human health. Conducted examinations show a need to subject medicines of natural origin to monitoring

\section{REFERENCES}

BLICHARSKAE., KOCJAN R., BŁAŻEWICZA. 2007. Oznaczanie zawartości żelaza, manganu, cynku, miedzi, kadmu i ołowiu w herbatkach ziołowych. Brom. Chem. Toksykol. XL, 1: 57-62.

DMOCHOWSKI D., PRĘDECKA A., MAZUREK M., PAWLAK A. 2011. Ocena zagrożeń związanych $z$ emisją metali ciężkich w aspekcie bezpieczeństwa ekologicznego na przykładzie ogródków działkowych w aglomeracji miejskiej. PPMPL 3, 17: 257-265.

GRUKA-KRÓLIKOWSKA S., WACŁAWEK W. 2006. Metale w środowisku. Cz. II. Wpływ metali ciężkich na rośliny. CDEM 11, 1-2: 1-16.

KABATA-PENDIAS A., PENDIAS H. 1999. Biogeochemia pierwiastków śladowych. PWN, Warszawa.

KICIŃSKA A. 2011. Formy występowania oraz mobilność cynku, ołowiu i kadmu w glebach zanieczyszczonych przez przemysł wydobywczo-metalurgiczny. Ochrona Środowiska i Zasobów Naturalnych 49: 152-162.

KOWOL J., WIECHUŁA D., KWAPULIŃSKI J., MIROSŁAWSKI J., OTRĘBSKA B., RABSZTYN E., JAKUBOWSKA J., KARPIŃSKA K., JEZIORSKA R. 2005. Zastosowanie

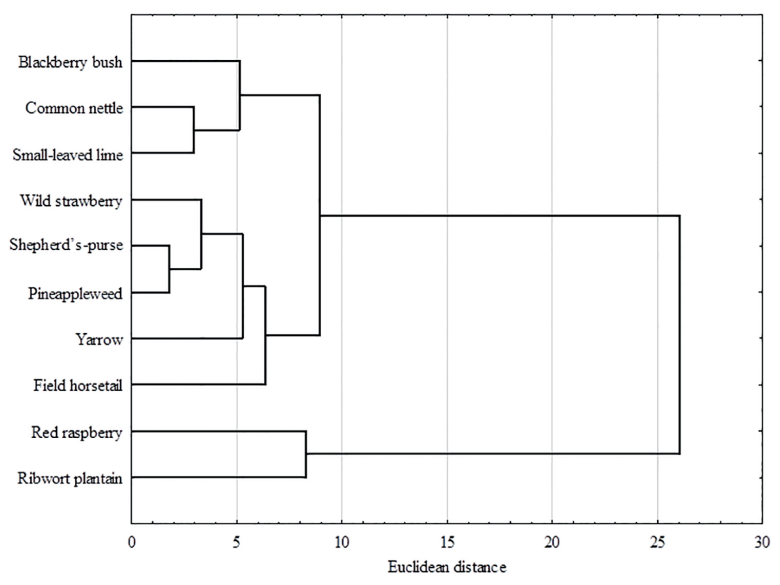

Fig. 5. Dendrogram, which illustrates resemblance of zinc accumulation by individual species of medicinal plants

of trace elements concentration, as well as to conduct specific environmental research for intoxicants concentration, in order to appoint cultivation positions or eliminate places of the medicinal plants collection [Blicharska et al. 2007, Wiechuła et al. 2013].

\section{CONCLUSIONS}

1. Lead concentration in most of studied medicinal plants exceeded the value of $10 \mu \mathrm{g} / \mathrm{g}$, which is the upper limit of this element concentration in medicinal plants established by WHO. Zinc concentration in examined plants was greater than this element concentration, indicated on free from pollutants areas.

2. Lead and zinc concentration in individual plants as well as calculated coefficients show a specificity of plant species with reference to collection and accumulation of metals. współczynników chemoekotoksykologicznych w ocenie stopnia kontaminacji roślin leczniczych metalami. Brom. Chem. Toksykol. Supl. XXXVIII: 283-286.

LOSKA K., WIECHUŁA D., PELCZAR J., 2005. Application of enrichment factor to assessment of zinc enrichment/ depletion in farming soils. Communications in Soil Science and Plant Analysis 36, 9-10: 1117-1128.

ŁASZEWSKA A., KOWOL J., WIECHUŁA D., KWAPULIŃSKI J. 2007. Kumulacja metali $w$ wybranych gatunkach roślin leczniczych z terenu Beskidu Śląskiego i Beskidu Żywieckiego. Problemy Ekologii 11, 6: 285-291.

NADGÓRSKA-SOCHA A., PTASIŃSKI B., KITA A., 2013. Heavy metal bioaccumulation and antioxidative responses in Cardaminopsis arenosa and Plantago lanceolata leaves from metalliferous and non-metalliferous sites: a field study. Ecotoxicology 22, 9: 1422-1434.

OSTROWSKA A., GAWLIŃSKI S., SZCZUBIAŁKA Z. 1991. Metody analizy i oceny właściwości gleb i roślin. Instytut Ochrony Środowiska, Warszawa. 
PASIECZNA A., DUSZA-DOBEK A., KOWALSKA Z. 2010. Szczegółowa mapa geochemiczna Górnego Śląska. Państw. Inst. Geol, Warszawa.

SARMA H., DEKA S., DEKA H., SAIKIA RR. 2011. Accumulation of Heavy Metals in Selected Medicinal Plants. Rev Environ Contam Toxicol 214: 63-86.

SROGI K. 2005. Poziomy Cd, Pb i Cu w glebie i w surowcach zielarskich. Brom. Chem. Toksykol. XXXVIII, 2: 183-194.

STAWINOGAD., KOWOL J., BOGUNIAM., DRUŻBAD., URBAN A., LIBROWSKA H. 2007. Metody ustalania rzeczywistej intoksykacji roślin leczniczych metalami toksycznymi. Farm. Przegl. Nauk. 10: 27-30.

SZWALEC A., MUNDAŁA P., KĘDZIOR R. 2013. Cadmium, lead, zinc and copper content in herbaceous plants overgrowing furnace waste landfill. Environmental Protection and Natural Resources 24, 3: 33-37.
WANG Y., ZHAN M., ZHU H., GUO S., I IN. 2012. Distribution and accumulation of metals in soils and plant from a leadzinc mineland in Guangxi, South China. Bull Environ Contam Toxicol 88: 198-203.

WHO (World Health Organization). 1989. Evaluation of Certain Food Additives and Contaminants; 33rd report of the Joint FAO/WHO Expert Committee on Food Additives; Technical Report Series 776. WHO, Geneva.

WIECHUŁA D., DOCZEKALSKA M., PIS A. 2013. Ocena fitokumulacji ołowiu i cynku w roślinach leczniczych z terenów pozyskiwania surowców zielarskich w województwie dolnośląskim. Brom. Chem. Toksykol. XLVI, 1: 96-104. 